\title{
Green soybean seeds: effect on physiological quality
}

\author{
Sheila Bigolin Teixeira1 ${ }^{1}$ Joseano Graciliano da Silva ${ }^{1 *}$ (i) Michele Renata Revers Meneguzzo $^{2}$ (i) \\ Andrea Bicca Noguez Martins ${ }^{1}$ Geri Eduardo Meneghello ${ }^{(}$Lilian Vanussa Madruga de Tunes ${ }^{1}$ (D)
}

${ }^{1}$ Programa de Pós-graduação em Ciência e Tecnologia de Sementes, Faculdade de Agronomia Eliseu Maciel, Universidade Federal de Pelotas (UFPel), 96160-000, Pelotas, RS, Brasil. E-mail: joseano_agronomo@outlook.com. "Corresponding author.

${ }^{2}$ Programa de Pós-graduação em Agronomia, Universidade de Passo Fundo (UPF), Erechim, RS, Brasil.

ABSTRACT: The objective of this research was to assess the manner in which the presence of green soybean seeds affects their physiological quality. In this study, six lots of soybean seeds of cultivar 5958RSF IPRO with 0, 0, 7, 8, 16 and 18\% of green seeds were examined. The tests done included the first germination count, germination, electrical conductivity, field emergence, accelerated aging, emergence speed index, Tetrazolium, length, dry mass and seedling growth curve. Results were tested employing the normality test and analysis of variance, and the means were compared by the Tukey test at $5 \%$ probability level, employing the Rbio statistical program. Growth data were analyzed by the nonlinear regression analytical method, using the SigmaPlot 12.0 software. The viability and vigor of the greenish seeds were confirmed to reveal higher deterioration, proportional to the percentage of seeds in which the cotyledons had green pigmentation, indicating that the presence of chlorophyll caused the physiological quality of the soybean seeds to decrease.

Key words: abiotic stress, decay, seedling growth, Glycine max.

Sementes de soja esverdeada: efeito na qualidade fisiológica

RESUMO: Neste trabalho o objetivo foi avaliar a influência da presença de sementes esverdeadas de soja na sua qualidade fisiológica. Para tanto, foram utilizados seis lotes de sementes de soja da cultivar 5958RSF IPRO com 0, 0, 7, 8, 16 e 18\% de sementes esverdeadas. Os testes realizados foram: primeira contagem de germinação, germinação, condutividade elétrica, emergência em campo, envelhecimento acelerado, indice de velocidade de emergência, tetrazólio, comprimento, massa seca e curva de crescimento de plântulas. Os resultados foram submetidos ao teste de normalidade e análise de variância, seguido de comparações de médias, pelo teste de Tukey ao nivel de $5 \%$ de probabilidade, com auxilio do programa estatístico Rbio. Os dados de crescimento foram submetidos à análise de regressão não-linear, utilizando o software SigmaPlot 12.0. Para as sementes esverdeadas, constata-se menor viabilidade e vigor devido a maior deterioração, proporcional a porcentagem de sementes com pigmentação verde nos cotilédones, de forma que a presença de clorofila reduz a qualidade fisiológica de sementes de soja.

Palavras-chave: estresse abiótico, deterioração, crescimento de plântulas, Glycine max.

\section{INTRODUCTION}

Several factors may influence the soybean seed quality [Glycine $\max$ (L.) Merrill] during production, in the course of seed maturation. This, in fact, is because of the factors linked with biotic and / or abiotic stresses (e.g. high and dry temperatures) can induce premature plant maturation and; therefore, yield greenish-colored seeds, which directly affect the physiological quality of the soybean seed lots (ZORATO et al., 2007; FRANÇA NETO et al., 2012; ARRUDA et al., 2016). This greenish hue is imparted by the chlorophyll present in the seed structures, particularly in the cotyledons, as this molecule is hard to degrade, principally due to the enzyme action being interrupted prior to the complete degradation of the chlorophyll (BROWN, 2017).

Chlorophyll degradation is closely linked to the levels of water and ethylene present (HEATON \& MARANGONI, 1996), due to which, this phenomenon is magnified during the concluding stages of seed formation. Chlorophyll degradation is thus caused by the sharp drop in the water content due to the photoassimilate translocation process being interrupted, thus resulting in the delay in maturation (CARVALHO \& NAKAGAWA, 2012). Under 
such conditions, the expectancy of physiological maturity exerts a direct effect on the final quantity of chlorophyll present in the seed tissue, as well as in their lower filling, and reduction in size (FRANÇA NETO et al., 2005; PARDO et al., 2015).

Earlier studies highlighted the fact that the green seeds present in the soybean seed lots have induced the decline in their physiological potential (ZORATO et al., 2007; CICERO et al., 2009; FRANÇA NETO et al., 2012; BROWN, 2017). Although, several studies revealed a negative correlation between the presence of green soybean seeds and seed quality, no clear evidence is available as yet on the influence exerted by the chlorophyll on seeds (TEIXEIRA et al., 2011).

When chlorophyll continues to be reported in the soybean, in the physiological maturity stage, it aggravates the oxidation of the reserve tissues in the soybean, often impeding the continuation of the growth of the embryonic axis and complete seedling formation in the field. Therefore, the prior awareness of the variables that may negatively affect the physiological quality of the seed lot becomes critical for the incorporation of management practices, and can often lower the risk of harvesting seeds with questionable vigor; and subsequently, a seed lot of low quality.

Uniformity and total seedling growth are reliable seed vigor indicators, as they exhibit the integrity of the seedling reserves and their capacity to break down and utilize them. While certain lots were easy to distinguish through visualization of the seedling length the difference in seed vigor, sometimes it was crucial to acquire numerical values to characterize them more clearly, so that the most vigorous lots were the ones with the highest average values (OLIVEIRA et al., 2009).

Thus, seedling length determination characterized seed vigor. This could be ascertained by measures of physical magnitude, which in this scenario referred to the length, dry mass and seedling growth velocity and the presence of green soybean seeds, all of which affected the physiological quality.

\section{MATERIALS AND METHODS}

Six lots of soybean seed 5958RSF IPRO and sieve size of 6.5 to $7.5 \mathrm{~mm}$, acquired from the seed production fields, were used, in the municipality of São Luís Gonzaga - RS. The lots were categorized based on the presence of greenish seeds. Six replications of 100 seeds were done to accomplish this. They were externally analyzed or sectioned, and the values recorded were $0,0,7,8,16$, and $18 \%$.
The germination test $(\mathrm{G})$ involved four repetitions of four subsamples of 50 seeds each. After distributing the seeds among three sheets of paper $\left(\right.$ Germitest $\left.^{\mathbb{R}}\right)$ which had been moistened prior with distilled water equivalent to 2.5 times its dry weight, they were placed in a germination chamber and conditioned at $25^{\circ} \mathrm{C}$ with a 12-hour photoperiod. The first germination count (PCG) was done on day 5 after installation of the test, with the second count being accomplished on day 8, according to Seed Analysis Rules (Brazil). The findings were given in percentage.

The accelerated aging test (EA) was done, using 200 seeds from each batch. After evenly distributing them in a single layer on an aluminum screen present inside the gerbox, (to act as a separate compartment), $40 \mathrm{ml}$ of distilled water was added to each gerbox. These were placed in a Biological Oxygen Demand (BOD) chamber, set at $41{ }^{\circ} \mathrm{C}$ for 48 hours. After this time span, the germination test was conducted on these seeds, and counting was done on day 5 posttest installation, according to Seed Analysis Rules (Brazil).

The electrical conductivity (EC) was ascertained using 200 seeds, where two subsamples of 25 seeds were distributed in four replications. After weighing them in an analytical balance they were placed in plastic cups to which $70 \mathrm{ml}$ of deionized water was added and left for 24 hours at $25^{\circ} \mathrm{C}$. Using a bench conductivity meter, the electrical conductivity was measured and the results were expressed in $\mu \mathrm{S}$ $\mathrm{cm}^{-1} \mathrm{~g}^{-1}$ seed (CARVALHO et al., 2009).

The field emergence (EC) test was done in the beds, employing four replications of 50 seeds per linear meter, ensuring that the soil moisture was maintained as close to the field capacity as possible, via daily irrigation using a watering aid. From all the five sowing periods (DAS) the counts were recorded and extended to until the time complete stand stabilization occurred (16 DAS). The counts included only the emergent seedlings, those having both cotyledons exposed at the soil surface. These data were used to calculate the emergence speed index, employing the formula proposed by MAGUIRE (1962).

Seed vigor and viability in the different seed lots were determined using the Tetrazolium test. This involved using four repetitions of 50 seeds, evenly distributed on paper towels (Germitest ${ }^{\circledR}$ ) which had been moistened earlier with volumes of distilled water equal to about to 2.5 times their weight. Then they were transferred to a BOD type germinator for 16 hours at $25^{\circ} \mathrm{C}$ (FRANÇA-NETO et al., 1998). Next, the seeds in the BOD were immersed 
in tetrazolium solution $(0.075 \%)$ and maintained at 36 ${ }^{\circ} \mathrm{C}$, for three hours. On visual evaluation, the viability was assessed by the sum of the percentages of seeds from classes 1 to 5 ; the vigor level, from seed classes 1 to 3 ; and the unviable seeds, from the seed classes 6 to 8 . Classes 4 and 5 were also counted for nonvigorous viable seeds, and the results thus acquired were given in percentage $(\%)$.

To assess seedling length, four replicates of 20 seeds from each batch were arranged longitudinally on the upper one-third of Germitest ${ }^{\mathbb{R}}$ sheets, moistened earlier with distilled water, at 2.5 times the paper dry weight, as given in Seed Analysis Rules (Brazil). The rolls were then transferred to a germination chamber maintained at $25^{\circ} \mathrm{C}$ temperature and 12-hourphotoperiod. The seedling length was measured, every 12 hours, every day, from the radicle protrusion using a millimeter ruler, until day 8 after test installation, based on the methodology of Seed Analysis Rules.

When the evaluations were completed, the seedlings were separated into shoots and roots, packaged in Kraft paper bags and placed in a forcedair circulation oven, at $65^{\circ} \mathrm{C}$, until the seedling dry weight stabilized. Then, they were weighed in an analytical balance $(0.0001 \mathrm{~g})$, and the values were expressed as mg seedling-1.

Adopting the completely randomized design (DIC) the experiment was done using six lots and involving four repetitions. The data were tested using the Shapiro-Wilk normality test, followed by the analysis of variance, and the means were then compared using the Tukey test at the $5 \%$ probability level, employing the Rbio statistical program (BHERING, 2017). The growth data were subjected to nonlinear regression analysis and the SigmaPlot 12.0 software was used.

\section{RESULTS AND DISCUSSION}

Among the variables analyzed, statistically significant differences $(p<0.01)$ were noted for all of them, barring shoot length, the mean values of which were $12.13 \mathrm{~cm}$ when the final seedling length measurements were taken under laboratory conditions (Table 1). The root growth, during the initial germination phase, becomes predominant compared to the shoot (CARVALHO \& NAKAGAWA, 2012), and significant differences may be noticeable between the lots, in terms of

Table 1 - Summary of the analysis of variance for the variables of electrical conductivity (EC), first germination count (PCG), germination (G), emergency speed index (IVE), field emergency (EC), total length (CT), shoot length (CPA), shoot dry mass (MSPA), root length (CPR), root dry mass (MSR), vigor, viability (FEASIBILITY), moisture damage (DU 4 -5 and 6-8) in soybean seedlings. Pelotas - RS, UFPel, 2019.

\begin{tabular}{|c|c|c|c|c|}
\hline Variables & QMLots & QMError & Average & $\mathrm{CV} \%$ \\
\hline $\mathrm{G}$ & $301.17^{* *}$ & 9.42 & 88.00 & 3.50 \\
\hline PCG & $379.70^{* *}$ & 10.56 & 85.00 & 3.81 \\
\hline EA & $277.37^{* *}$ & 32.72 & 67.00 & 8.55 \\
\hline $\mathrm{CE}$ & $543.87^{* *}$ & 5.52 & 70.55 & 3.33 \\
\hline $\mathrm{EC}$ & $200.00^{* *}$ & 33.89 & 78.00 & 7.42 \\
\hline IVE & $12.04^{* *}$ & 0.71 & 12.72 & 6.64 \\
\hline VIGOR & $354.24^{* *}$ & 7.87 & 71.29 & 3.94 \\
\hline FEASIBILITY & $106.90^{* *}$ & 3.05 & 88.17 & 1.98 \\
\hline DU 4-5 & $94.87^{* *}$ & 6.28 & 13.67 & 18.33 \\
\hline DU 6-8 & $75.90^{* *}$ & 2.83 & 9.25 & 18.2 \\
\hline $\mathrm{CT}$ & $48.59^{* *}$ & 1.80 & 31.42 & 4.27 \\
\hline CPA & $2.33 \mathrm{~ns}$ & 0.87 & 12.13 & 7.70 \\
\hline $\mathrm{CR}$ & $33.55^{* *}$ & 1.18 & 19.29 & 5.64 \\
\hline MSPA & $0.02^{* *}$ & 0.004 & 119.79 & 5.47 \\
\hline MSR & $0.002^{* *}$ & 0.0003 & 18.06 & 9.69 \\
\hline GL & 5 & 18 & - & - \\
\hline
\end{tabular}

${ }^{* *}$ Significant at $1 \%(\mathrm{P}<0.01) ;{ }^{*}$ significant at $5 \%(\mathrm{P}<0.05) ;$ ns $=$ not significant at $5 \%$ probability $(\mathrm{P}<0.05)$ by Tukey test. QM $=$ mean square; $\mathrm{GL}=$ degree of freedom; $\mathrm{CV}=$ coefficient of variation. 
differences post-emergence, at the time plants get established and fully developed in the field.

Table 2 reveals that all the data appear similar to each other, with the physiological quality dropping to lower values proportional to the percentage of increase in the number of greenish seeds; this is accepted as normal because of the high rates of deterioration, which may result in decreased vigor and viability in a soybean seed lot (COSTA et al., 2001). Although, many seeds germinate up to the stage of developing into a seedling, the chlorophyll present in the seed reserve tissues clearly induces damage that can harm the establishment of the crop.

When germination was considered, the values were unsatisfactory only for the lot 6 seeds (18\% of greenish seeds), according to the standards set for the commercialization of soybean according to the Ministry of Agriculture, Livestock and Supply (MAPA). Results of this study concurred with those obtained by ZORATO et al., (2007), who reported that the greenish seeds present in the lot exerted a negative effect on the physiological quality.

The accelerated aging test promised to provide reliable estimates of the storage potential of the seed lots, because seeds of low quality deteriorate more rapidly when subjected to the unfavorable conditions of high temperature and relative humidity (MENDONÇA et al., 2000). In this study, the seed quality in lots containing 16 and $18 \%$ of green seeds (lot 5 and 6, respectively) was evidently much lower than that of the other lots (Table 2).

In terms of the electrical conductivity, the data (Table 2) revealed a greater electrolyte leakage in the lots having the highest percentage of green seeds (lot 6) but lower in lot 1 , showing 62\% difference between them. Therefore, the greenish colored seeds were reported to possess a poorer reorganization capacity of the membrane system (PARDO et al., 2015), apart from inducing losses in the reserve tissue, both of which make it conducive for pathogenic microorganisms to develop.

In this test, it was also possible to observe; that although lots 2, 4 and 6 have similar percentage of greenish seeds of lots 1, 3 and 5, respectively, did not have the same effect in integrity of membranes was reported, demonstrating a higher rate of deterioration, since in addition to the effect of green pigment on physiological quality is higher in the greenish seeds index, it is noticeable that the greater intensity of green hue affecting the cotyledons seeds will result in a lower batch quality (ZORATO et al., 2007).

Table 2 - Average values are listed for the variables of germination percentage (G), first germination count (PCG), electrical conductivity (CE), accelerated aging (EA), emergency speed index (IVE) and field emergency (EC), of six soybean seed lots having greenish hued seeds. Feasibility, vigor, moisture deterioration in classes 4-5 and 6-8. Total seedling length (TC), root length (CR), part dry mass (MSPA) and root (MSR) in six soybean seed lots having green seeds, in Pelotas - RS, UFPel, 2019.

\begin{tabular}{|c|c|c|c|c|c|c|}
\hline \multirow[t]{2}{*}{ Variables } & \multicolumn{6}{|c|}{ } \\
\hline & 1 & 2 & 3 & 4 & 5 & 6 \\
\hline $\mathrm{G}(\%)$ & $96 \mathrm{a}^{*}$ & $95 \mathrm{ab}$ & $89 \mathrm{bc}$ & $88 \mathrm{c}$ & $86 \mathrm{c}$ & $72 \mathrm{~d}$ \\
\hline PCG $(\%)$ & $94 \mathrm{a}$ & 93 a & $88 \mathrm{ab}$ & $85 \mathrm{~b}$ & $85 \mathrm{~b}$ & $67 \mathrm{c}$ \\
\hline EA $(\%)$ & $73 \mathrm{a}$ & $78 \mathrm{a}$ & $67 \mathrm{a}$ & $67 \mathrm{a}$ & $65 \mathrm{ab}$ & $53 \mathrm{~b}$ \\
\hline $\mathrm{CE}\left(\mu \mathrm{S} \mathrm{cm} \mathrm{c}^{-1} \mathrm{~g}^{-1}\right)$ & $55, .3 \mathrm{~d}$ & $71.9 \mathrm{~b}$ & $64.5 \mathrm{c}$ & $75.6 \mathrm{~b}$ & $66.3 \mathrm{c}$ & $89.6 \mathrm{a}$ \\
\hline $\mathrm{EC}(\%)$ & $86 a$ & $87 \mathrm{a}$ & $79 \mathrm{ab}$ & $71 \mathrm{~b}$ & $78 \mathrm{ab}$ & $71 \mathrm{~b}$ \\
\hline IVE & $15.1 \mathrm{a}$ & $14.2 \mathrm{ab}$ & $13.1 \mathrm{bc}$ & $11.1 \mathrm{~d}$ & $11.9 \mathrm{~cd}$ & $10.9 \mathrm{~d}$ \\
\hline Feasibility (\%) & $94 \mathrm{a}$ & 94 a & $88 \mathrm{~b}$ & $88 \mathrm{~b}$ & $82 \mathrm{c}$ & $83 \mathrm{c}$ \\
\hline Vigor (\%) & $85 \mathrm{a}$ & $80 \mathrm{a}$ & $71 \mathrm{~b}$ & $67 \mathrm{bc}$ & $64 \mathrm{c}$ & $61 \mathrm{c}$ \\
\hline DU 4-5 (\%) & $6 \mathrm{~d}$ & $10 \mathrm{~cd}$ & $14 \mathrm{bc}$ & $16 \mathrm{abc}$ & $16 \mathrm{ab}$ & $20 \mathrm{a}$ \\
\hline DU 6-8 (\%) & $4 \mathrm{c}$ & $5 \mathrm{c}$ & $8 \mathrm{bc}$ & $10 \mathrm{~b}$ & $14 \mathrm{a}$ & $14 \mathrm{a}$ \\
\hline $\mathrm{TC}(\mathrm{cm})$ & $36.3 \mathrm{a}$ & $32.6 \mathrm{~b}$ & $33.5 \mathrm{ab}$ & $29.2 \mathrm{~cd}$ & $30.6 \mathrm{bc}$ & $26.4 \mathrm{~d}$ \\
\hline $\mathrm{CR}$ & $23.5 \mathrm{a}$ & $20.0 \mathrm{~b}$ & $20.8 \mathrm{~b}$ & $16.8 \mathrm{~cd}$ & $19.2 \mathrm{bc}$ & $15.4 \mathrm{~d}$ \\
\hline MSPA (mg) & $130.2 \mathrm{a}$ & $129.6 \mathrm{ab}$ & $117.7 \mathrm{abc}$ & $115.0 \mathrm{bc}$ & $114.1 \mathrm{c}$ & $112.2 \mathrm{c}$ \\
\hline MSR (mg) & 20.9 a & $17.1 \mathrm{abc}$ & $19.9 \mathrm{a}$ & $15.9 \mathrm{bc}$ & $19.3 \mathrm{ab}$ & $15.2 \mathrm{c}$ \\
\hline
\end{tabular}

${ }^{*}$ Means followed by the same letter on the line do not differ statistically from each other at $5 \%$ probability of error by the Tukey test. Lots 1 to 6 represent $0,0,7,8,16$, and $18 \%$ respectively, of greenish-colored seeds. 
Considering emergence in the beds (Table 2), a significant decrease was evident in the physiological quality of these seeds in lot numbers $3,4,5$ and 6 , which contained more quantities of greenish seeds in the yield. Unevenness in seedling development was also visible, through IVE, which corresponds to the research of COSTA et al., (2001) in which indices above $10 \%$ render it unmarketable as seed. However, other authors have cited that the safe percentage for commercialization of greenish seeds is 9\% (PÁDUA et al., 2007).

The Tetrazolium test gave viability values similar to those acquired in the germination test, showing declining values as the presence of the green seeds escalated in the lots (Table 2). Seed vigor was evident as being even more accountable for this state, showing a sharper decrease in the 5 and 6 seeds lots, while the number of dead seeds (DU6-8) was proportional to the rise in the number of green seeds in the lots.

In their study, ZORATO et al., (2003) and ARRUDA et al., (2016) reported similar results by the presence of the green seeds found in class 3 (average vigor), but especially in classes 4 and 5 (viability). The greenish seeds are reported to be responsible for inducing seed death in substantial amounts (DU 6-8) (Table 2). In their research FRANÇA-NETO et al., (1998) cited that for any batch to be considered high quality, moisture damage in categories $4-5$ cannot go above $7 \%$. Therefore, lot 1 alone could be accepted as high quality, as it gave a value of only $6 \%$ for this category.
The data on seedling length explains embryo integrity and reserve tissue usability. In terms of total length (Table 2), there is an observable difference of 10 $\mathrm{cm}$ between lot 1 and lot 6 , which has been primarily attributed to the poorer root growth. While shoot length was not affected by the presence of green seeds, the dry weight of shoot was significantly decreased in the green seed lots. This is principally because the reserve tissue was damaged, which in turn induced cotyledon necrosis. In their research ARRUDA et al., (2016) demonstrated that seed lots having green seed indices greater than $17 \%$ should not be employed in sowing.

The seedling length-related growth curves fitted the three-parameter sigmoidal model, showing $\mathrm{R}^{2}$ greater than $0.99(\mathrm{P}<0.01)$. The curves enabled seedling growth behavior to be assessed, as it was possible to identify similarity in the growth among the lots when the germination process was beginning, but over time, dissimilarities emerged, particularly in terms of the root length (Figures 1A and 1C).

Between the 72 and 156 hours after sowing, the seedling length showed no further increase, but this is not so clearly evident in the lots containing a higher percentage of greenish seeds. Depending upon the rapidity of the growth of the seedling, the faster it will get established in the field; and therefore, the less it will be damaged by unfavorable environmental conditions, even related in terms of its capacity to compete with weeds and reveal their productive potential (ZORATO et al., 2003; ARRUDA et al., 2016; ZORATO et al., 2007).

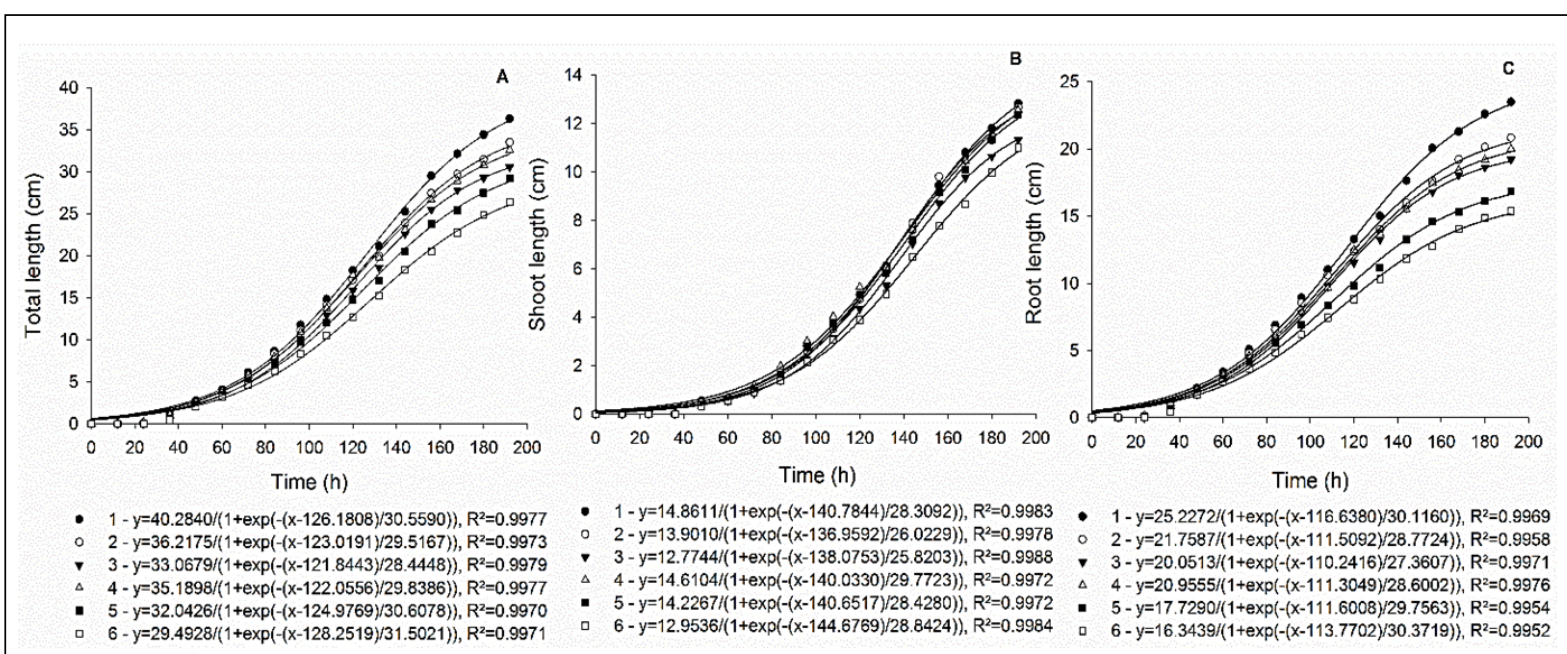

Figure 1 - Seedling growth curve, evaluated every $12 \mathrm{~h}$, through total seedling length (A), shoot length (B) and root length (C), drawn from sowing six soybean seed lots, having greenish seeds, in Pelotas - RS, UFPel, 2019. Lots 1 to 6 represent 0, 0, 7, 8, 16, and 18\% respectively, of greenish colored soybean seeds. 


\section{CONCLUSION}

Green soybean seeds are lower in viability and vigor due to the presence of chlorophyll which induced a decrease in their physiological quality.

\section{DECLARATION OF CONFLICT OF INTERESTS}

The authors declare no conflict of interest. The founding sponsors had no role in the design of the study; in the collection, analyses, or interpretation of data; in the writing of the manuscript, and in the decision to publish the results.

\section{ACKNOWLEDGEMENTS}

This work was carried out with the support and funding of $\mathrm{CNPq}$, National Council for Scientific and Technological Development - Brazil, and by the Coordination for the Improvement of Higher Education Personnel (CAPES).

\section{AUTHORS' CONTRIBUTIONS}

All authors contributed equally for the conception and writing of the manuscript. All authors critically revised the manuscript and approved of the final version.

\section{REFERENCES}

ARRUDA, M. H. M. et al. Physiological quality of soybean seed lots with different percentages of greenish seeds. Magistra, v.28, p.194-200, 2016. Available from: <https://magistraonline.ufrb.edu. br/index.php/magistra/article/view/79/247>. Accessed: Jul. 6, 2019.

BHERING, L. L. Rbio: a tool for biometric and statistical analysis using the $\mathrm{r}$ platform. Crop Breeding and Applied Biotechnology, v.17, p.187-190, 2017. Available from: <http:// dx.doi.org/10.1590/1984-70332017v17n2s29>. Accessed: Jul. 7, 2019. doi: 10.1590/1984-70332017v17n2s29.

BROWN, C. Green seed, agronomy Guide for Field Crops. Ministry of Agriculture, Food and Rural Affairs. 2017. Available from: <http://www.omafra.gov.on.ca/english/crops/field/soybeans. html>. Accessed: Apr. 09, 2019.

CARVALHO, L. F. et al. Influence of soybean seed soak temperature on electrical conductivity test for physiological quality evaluation. Revista Brasileira de Sementes, v.31, p.9-17, 2009. Available from: <http://dx.doi.org/10.1590/S0101-31222009000100001>. Accessed: Jul. 11, 2019. doi: 10.1590/S0101-31222009000100001.

CARVAlHO, N. M.; NAKAGAWA, J. Sementes: Ciência, Tecnologia e Produção. $5^{\text {a }}$ ed. Jaboticabal: FUNEP, 2012. 590p.

CICERO, S. M. et al. Use of chlorophyll fluorescence sorting to improve soybean seed quality. Revista Brasileira de Sementes, v.31, p.145-151, 2009. Available from: <http://www.scielo.br/ scielo.php?script $=$ sci arttext\&pid $=$ S0101-31222009000400017>. Accessed:Apr. 14, 2019. doi: 10.1590/S0101-31222009000400017.

COSTA, N. P. et al. Effect of green seeds on physiological quality of soybean seeds. Revista Brasileira de Sementes, v.23, p.102-
107, 2001. Available from: <https://ainfo.cnptia.embrapa.br/digital/ bitstream/item/49564/1/ABRATES3.PDF>. Accessed: Jul. 10, 2019.

FRANÇA-NETO, J. B. et al. Tetrazolium test in soybean seeds. Londrina: EMBRAPA-CNPSo, (EMBRAPA-CNPo. Documentos, 116). 1998. 72p. Available from: <https://www.agrolink.com.br/ downloads/TRETRAZ\%C3\%93LIO.pdf>. Accessed: Jul. 12, 2019.

FRANÇA-NETO, J. B. et al. Greenish soybean seed and its physiological quality. Londrina: Embrapa Soja, 2005.4p. (Circular Técnica 38). Available from: <https://ainfo.cnptia.embrapa.br/ digital/bitstream/CNPSO-2009-09/25641/1/circular38.pdf>. Accessed: Apr. 10, 2019.

HEATON, J. W.; MARANGONI, A. G. Chlorophyll degradation in processed foods and senescent plant tissues. Trends in Food Science \& Technology, v.7, p.8-15, 1996. Available from: <https://www. sciencedirect.com/science/article/pii/0924224496813525?via\%3Dih ub>. Accessed: Apr. 10, 2019. doi: 10.1016/0924-2244(96)81352-5.

MAGUIRE, J. D. Speed of germination-aid selection and evaluation for seedling emergence and vigor. Crop Science, v.2, p.176-177, 1962. Available from: <http://dx.doi.org/10.2135/crop sci1962.0011183X000200020033x>. Accessed: Jul. 13, 2019. doi: 10.2135/cropsci1962.0011183X000200020033x

MENDONÇA, E. A. F. et al. Teste de deterioração controlada em sementes de brócoli (Brassica oleraceae L.) var. itálica. Revista Brasileira deSementes, v.22,p.280-287,2000.Available from: $<$ http:// dx.doi.org/10.17801/0101-3122/rbs.v22n1p280-287>. Accessed: Jul. 14, 2019. doi: 10.17801/0101-3122/rbs.v22n1p280-287.

OLIVEIRA, A. C. S. et al. Testes de vigor em sementes baseados no desempenho de plântulas. InterSciencePlace, v.2, p.1-21, 2009. Available from: $<$ http://www.interscienceplace.org/isp/index.php/ isp/article/view/35>. Accessed: Jul. 15, 2019.

PÁDUA, G. P. et al. Tolerance level of green seed in soybean lots after storage. Revista Brasileira de Sementes, v.29, p.112120, 2007. Available from: <http://dx.doi.org/10.1590/S010131222007000300015>. Accessed: Jul. 16, 2019. doi: 10.1590/ S0101-31222007000300015.

PARDO, F. F. et al. Qualidade fisiológica de sementes de soja esverdeadas em diferentes tamanhos. Revista de Agricultura Neotropical, v.2, p.39-43, 2015. Available from: $<$ http://periodicosonline.uems.br/index.php/agrineo/article/ view/275/683>. Accessed: Jul. 17, 2019.

TEIXEIRA, R. N. et al. Green seed percentage, chlorophyll content and soybean batch quality. Informativo ABRATES, v.21, p.39, 2011. Available from: <https://ainfo.cnptia.embrapa.br/digital/ bitstream/item/40264/1/136-2.pdf>. Accessed: Jan. 11, 2020.

ZORATO, M. F. et al. Sementes esverdeadas em soja: testes alternativos para predizer sua armazenabilidade e seu efeito na produtividade. Informativo Abrates, v.13, p.295, 2003. Available from: <http://dx.doi.org/10.1590/S010131222007000100001>. Accessed: Jul. 21, 2019. doi: 10.1590/ S0101-31222007000100001.

ZORATO, M. F. et al. Presença de sementes esverdeadas em soja e seus efeitos sobre seu potencial fisiológico. Revista Brasileira de Sementes, v.29, p.11-19, 2007. Available from: <http://dx.doi. org/10.1590/S0101-31222007000100002>. Accessed: Jul. 22, 2019. doi: 10.1590/S0101-31222007000100002. 